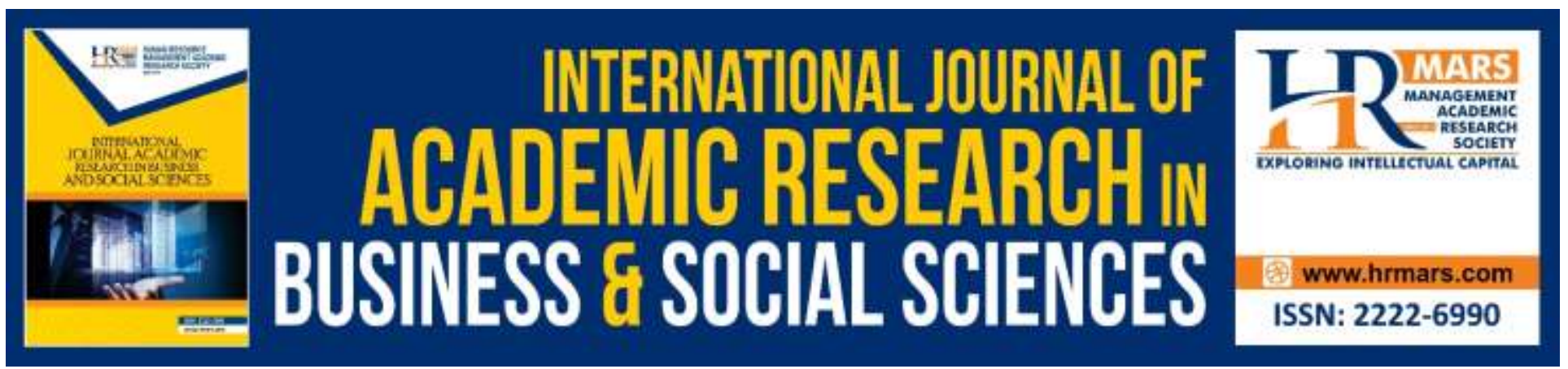

\title{
Punishment for Apostasy: A Review and Choosing the Right Perspective (Tarjih)
}

Santhira Morgan, Jasni bin Sulong

To Link this Article: http://dx.doi.org/10.6007/IJARBSS/v10-i6/7370

DOI:10.6007/IJARBSS/v10-i6/7370

Received: 22 April 2020, Revised: 27 May 2020, Accepted: 11 June 2020

Published Online: 30 June 2020

In-Text Citation: (Morgan \& Sulong, 2020)

To Cite this Article: Morgan, S., \& Sulong, J. bin. (2020). Punishment for Apostasy: A Review and Choosing the Right Perspective (Tarjih). International Journal of Academic Research in Business and Social Sciences, 10(6), 739-750.

Copyright: (C) 2020 The Author(s)

Published by Human Resource Management Academic Research Society (www.hrmars.com)

This article is published under the Creative Commons Attribution (CC BY 4.0) license. Anyone may reproduce, distribute, translate and create derivative works of this article (for both commercial and non-commercial purposes), subject to full attribution to the original publication and authors. The full terms of this license may be seen at: http://creativecommons.org/licences/by/4.0/legalcode

Vol. 10, No. 6, 2020, Pg. 739 - 750

http://hrmars.com/index.php/pages/detail/IJARBSS

JOURNAL HOMEPAGE

Full Terms \& Conditions of access and use can be found at http://hrmars.com/index.php/pages/detail/publication-ethics 


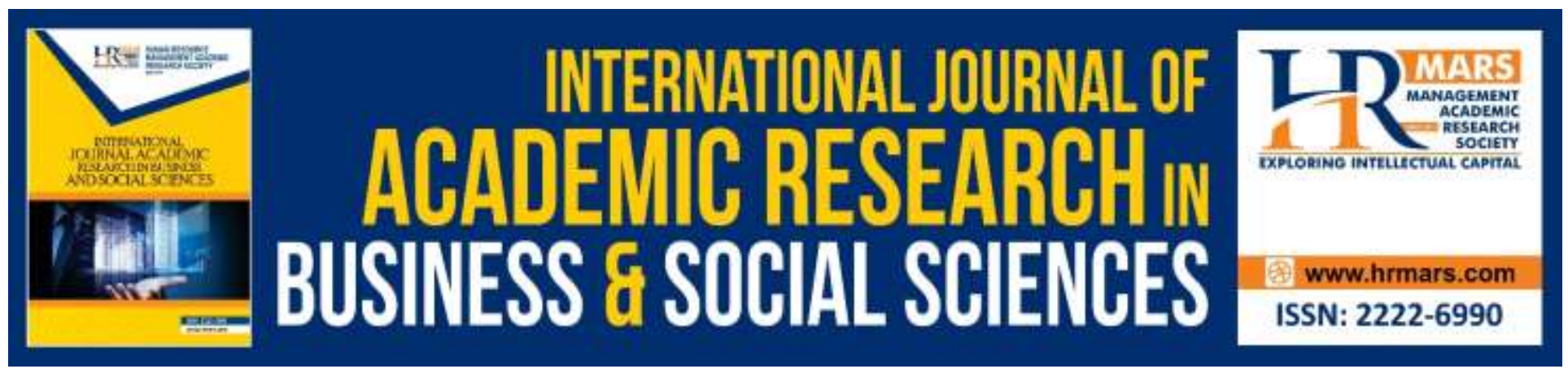

\title{
Punishment for Apostasy: A Review and Choosing the Right Perspective ( Tarjih)
}

\author{
Santhira Morgan, Jasni bin Sulong \\ School of Humanities, Universiti Sains Malaysia.
}

\begin{abstract}
Apostasy is the act of breaking out of a current religion, by embracing another religion or by choosing not to believe in any religions. Religion is a belief that no one is forced to obey, including Islam. No one is not forced to accept Islam. However, after embracing Islam, one is not allowed to leave. This is because Islam is a religion that is coordinated and has certain regulations. One of the rules outlined is that one cannot renounce Islam after believing it because it is illegal to flee from obedience and obligations. In Islam, there are certain punishments which ranges from counselling to the death penalty. Muslim scholars unanimously agree that the punishment for apostasy is first repentance and a failure to do so results in death. But contemporary Islamic scholars, on the other hand, consider that one could leave Islam if one does not commit rebellion and remain silent. This justification is based on a person's choice to choose his religion. Therefore, this paper will look at this aspect from the standpoint of Islamic law and the provisions of the current law in Malaysia.
\end{abstract}

Keywords: Apostacy, Islam, Punishment, ljtihad, Death Penalty, Tarjih.

\section{Introduction}

In Malaysia, apostasy among the Malays is a sensitive issue. This is because Islam relates to the interpretation of the Malays (Federal Constitution, Article 160). Every Malay is considered a Muslim. Islam is the religion of his ancestors and it is the religion of the state. Since independence, Islam is acclaimed as the religion for the Federation. In line with Islamic principles, a prohibitive harsh punishment of death awaits apostates, which resembles the same kind of punishment for drug trafficking. The discussion among scholars from the past to the present regarding punishment for Muslim apostate has brought about the notion that the punishment for apostasy in Islam is not mandatory. Therefore, the purpose of this study is to disclose the arguments and choosing the right perspective that should be emphasised in shariah law.

\section{The Definition of Apostacy}

The discussion on the definition can be analysed from two perspectives, that is, from the perspective of language and of its application.

When it comes to language, the word apostasy is originated from Arabic term, irtadda, yartaddu, riddah or murtad (Ibn Manzur, 1414). In al-Qur'an, the word yartaddu has been mentioned 
in several verses such as Q2:217, Q5:54, Q3:81, Q5:61, Q9:66, Q4:137 and Q16:106, which means, "turn from", "renounce" and "those who disbelieve after having believed". However, the term riddah or irtidad are not found being used in the Quran (Simpson, et. al., 1989). Apostasy or 'riddah' or 'irtidad' in Islam, means returning to a previous state. The words ' $r a$ ' and ' $d a l$ ' (radd) give the meaning of returning to the previous state or returning to the origin (Mohamad, 1993). According to the Oxford Dictionary of Islam (1989), apostasy is the renunciation of one's religion.

Meanwhile, from the perspective of the application, the word riddah or apostasy means someone who leaves Islam to another religion and becomes a disbeliever of Allah SWT (kufur). In other words, apostasy can be defined as the conscious abandonment of Islam by a Muslim in by word or through deed (Hassan \& Ali, 1987). It includes the act of converting to another religion or nonacceptance of faith to be irreligious, by a person who was born in a Muslim family or who had previously accepted Islam. According to the classical legal doctrine, apostasy in Islam includes not only an explicit renunciation of the Islamic faith (whether for another religion or irreligiosity), but also any deed or utterance implying unbelief, such as one denying a "fundamental tenet or creed" of Islam (Wikipedia, 2020).

Islamic jurists did not formulate general rules for establishing unbelief, instead they compiled lengthy lists of statements and actions which in their view implied apostasy. The Islamic jurist have opinions on the meaning of apostasy, as below:

i. The Hanafi school says, apostasy is like returning from faith to unbelief (Ibn Abidin, 1992). From belief and worship of Allah SWT to another god or becoming an atheist.

ii. The Maliki school said says, apostasy takes place when a Muslim expressly rejects any word or deed that contains disbelief (al-Maliki, 1989). As a result, he becomes an infidel.

iii. The Syafie school is of the opinion that apostasy is when someone condemns Islam with intention through utterance, or by any act of mocking, defaming or making fun of Islam. (Syarbini, 1994).

iv. The Hanbali school says, apostasy is whenever one voluntarily accepts Islam as a mumayyiz and after having accepted Islam, later doubts and jokes about Islam and he feels that Islam is forced upon him (Ibn Qudamah, 1983).

According to Jalal al-Din (1959) while doing exegesis on Q2:217, says that the apostate is someone who returns to the state of kufr and becomes a disbeliever after renouncing Islam. In other words, an apostate is someone who turns from his religion and becomes a person with no faith in Allah.

However, apostasy does not include individuals who are forced to embrace Islam under conditions of duress or acts against Islam or conversion to another religion that is involuntary, or done as concealment out of fear of persecution or war (taqiyya or kitman).

\section{Methodology}

This thesis makes use of qualitative research strategy with Library Research as the primary source of data collection to gather non-numerical data to get answers to 'how' and 'why' a certain punishment is meted out (Given, 2008). Qualitative research approaches are employed across many academic disciplines, focusing particularly on the human elements of the social and natural sciences. Qualitative research is widely used by political science, social work, and education researchers (Given, 2008). Qualitative researches are very interpretative. 
INTERNATIONAL JOURNAL OF ACADEMIC RESEARCH IN BUSINESS AND SOCIAL SCIENCES

Vol. 10, No. 6, June, 2020, E-ISSN: 2222-6990 @ 2020 HRMARS

\section{Methods of Data Collection}

The researcher applied 'library research' his was done in order to collect adequate and relevant data to address the research objectives of this study.

\section{Library Research}

Data gathered via library research is categorized as the secondary data. Secondary data means the data is readily available and is used by anyone besides researchers. This means that secondary data is not originally collected but rather obtained from published or unpublished sources (Walliman, 2011). Library research includes data gathered from textbooks, published Phd dissertation, published Masters thesis, published academic papers, The Quran, The Sunnah and Journals.

- Convergence - "data from different sources, methods, investigators, and so on will produce evidence that will result in a single proposition about some social phenomenon."

- Inconsistency - "multiple sources, methods, and so on.... [generate] range of perspectives or data that do not confirm a single proposition about a social phenomenon," and

- Contradiction - "the use of multiple methods results "in opposing views of the social phenomenon studies."

Mathison asserts that the researchers need to "make sense of what they find." In Mathison's view, this moves "the focus on triangulation away from a technological solution for ensuring validity and places the responsibility with the researcher for the construction of plausible explanation about the phenomena being studied (Mathison, (1988)."

\section{Analysis of Legal Sources on Apostasy Punishment}

The main sources of Islamic law are the Quran and al-Hadith. These two sources are the highest references in Islam and will become the source of discussion regarding punishment for the apostasy.

\section{Source from al-Qur'an}

There are several verses in the Qur'an that provide for apostasy. These verses tell us that apostasy is not just a forbidden and sinful act, but also underlineds a specific torment for the apostate in this world and Hereafter.

In this world, the apostate is considered a non-believer and his deeds have become meaningless. This consequence is in line with the interpretation of Jalal al-Din (1959) on apostasy in Surah Al-Baqarah (Q2:217):

"And whoever of you reverts from his religion [to disbelief] and dies while he is a disbeliever - for those, their deeds have become worthless in this world and the Hereafter, and those are the companions of the Fire, they will abide therein eternally". According to al-Maraghi (2001), a Muslim who apostates will find his worships during Islam become void and futile. In this world, he/she becomes a losers which according to the Islamic law, will result in his/her marriage separation and he/she will have no more right to inheritance. Another loss that is mentioned by al-Maraghi is that the apostate will be sentenced to death during his lifetime. Furthermore, he/she will be tormented by hell-fire for his/her rebellion from faith in the Hereafter.

Meanwhile, in the Tanwir al-Miqbas min Tafsir Ibn 'Abbas, Ibn Abbas (2007) has said that the fate of the apostate is that he/she should return to the state of Kufr, which is a state that was ruled by non-Muslims. This premise is based on throughout early Islam, the situation is like returning to Mecca after happening apostasy in Madinah. The Mecca, in this case, was the state he/she was in 
before their conversion to Islam. Ibn Abbas (2007) also reiterated that whoever renounces Islam and dies in his disbelief, he/she is considered as fallen and all their good deeds are rejected in the Hereafter.

Similarly, according to Jalal al-Din (1959), apostasy causes all the good deeds done while being a Muslim becomes meaningless. He reiterated that whoever turns from his religion, and dies disbelieving - their, good works become invalid, in this world and the Hereafter. Thus they will not count for anything and will not result in any reward. But, if that person were to return to Islam again, his original deeds would not be invalidated, and he will be rewarded for them, and he would not have to repeat them, such as performing the Hajj. In another verse on apostasy Allah says in Surah An-Nahl 106:

He who disbelieves in Allah after his having believed, not he who is compelled while his heart is at rest on account of faith, but he who opens (his) breast to disbelief-on these is the wrath of Allah, and they shall have a grievous chastisement.

Ibn Abbas (2007) interprets this verse as, whoso disbelieved in Allah after his belief in Him, deserves Allah's wrath (save him who is forced thereto) except the person who is coerced into disbelief (and whose heart is still content with Faith). This verse suggests that, whoever disbelieves in Allah after believing in him, he deserves Allah's wrath unless he is forced to disbelieve.

In essence, Ibn Abbas (2007) is interpreting the verse as saying that awful torment awaits anyone who utters disbelief after having had believed in Allah unless if that person was forced to utter those words. Similarly, Jalal al-Din (1959) expresses the same opinion in his commentary. Whoever is compelled, to pronounce a statement of unbelief and so pronounces it, while his heart remains faithful there is no chastisement but he who opens up his breast to unbelief there is a great chastisement for him.

The religious condemnation of apostasy does not involve any existing infidels or non-Muslims. They are not forced to embrace Islam and al-Qur'an has clearly underlined that every human beings have full freedom to choose their own beliefs. This position was underlined in Surah al-Baqarah that "there is no compulsion in religion" (Q2:256). Therefore, the verse becomes an argument to rejects the view that Islam was imparted through the sword (battle)(al-Maraghi, 2001). The same philosophy was explained in Surah al-Kahfi in which Allah S.W.T. has said:

"And say: the truth is from your Lord, so whoever wills - let him believe; and whoever wills - let him disbelieve" (Q18:29).

The same gist was echoed in Surah Yunus that there is no use to force a religion unto someone as we humans are unable to achieve their acceptance of Iman with coercion. Allah S.W.T said:

"And had your Lord willed, those on earth would have believed - all of them entirely. Then, [O Muhammad], would you compel the people so that they become believers?" (Q10:99)

Even though the non-believers is no compulsion to Islam, al-Qur'an still explains that they will be punished in the Hereafter for such distrust. The retribution of hell is reaffirmed in Surah al-Kahfi which Allah S.W.T has said:

"And say: the truth is from your Lord, so whoever wills - let him believe; and whoever wills - let him disbelieve. Verily We (Allah S.W.T) have prepared for the injustice (the disbelievers) Hell." (Q18:29). 
The fate of those who do not believe Islam is that they will be thrown into hell, either infidel or apostate. This is because every human being needs to seek knowledge and with that, they think about divinity and embrace the truth of faith.

Based on the sources of Qur'anic verses, there is no single verses that underlined penalty for apostate while living in this world, except for separating marriage and barred from inheritance. No direct Qur'anic verse tells of the death penalty for apostasy, except the in the explanation of the verses as was expressed by al-Maraghi (2001). In the light of these severe penalties, there should be a special verse about the consequence.

\section{Source from Hadith}

Hadith is the second source in Islam, which has the role of supporting, explaining, limiting or enhancing what is not found in the Qur'an. Based on the study, the hadith has provided more detailed information on the punishment for apostates especially while living in this world.

Based on three hadiths that are obtained from the Sahih al-Bukhari (1414), the Prophet SAW has said that the penalty for apostate is death. The first hadith was reported by Ibn Abbas that the Prophet has said, "Whoever changes their religion, kill them". The full narrative (matan) of this hadith in more detail is as follows:

Ali burnt some people and this news reached Ibn 'Abbas, who said, Had I been in his place I would not have burnt them, as the Prophet said, 'Don't punish (anybody) with Allah's Punishment.' No doubt, I would have killed them, for the Prophet said, 'If somebody (a Muslim) discards his religion, kill him.'

Second hadith was reported by Mu'adh bin Jabal who has told another Companion, Abu Musa alAsh'ari, that executing the apostate was the ruling of God and His Messenger (al-Bukhari, 1414). And third, the Prophet SAW said that a Muslim could only be executed for crimes of murder, adultery and apostasy. All of these hadiths generally stated that the penalty for apostasy is death without considering the context of apostasy in any case.

Many muhaddithin including Imam Al-Bukhari (1414) and Imam Muslim (1330) narrated this particular hadith in their books. In other commentaries, Imam Al-Bukhari (1414) also narrated as below:

Not halal the blood of Muslim who had confessed that there is no god except Allah and I am Allah's messenger, except for three situations: life for life, and married fornicator, and leaver of Islam and deserter from the community.

The same tone was narrated in the Sahih Muslim (1330), as below:

Not halal the blood of Muslim who had confessed that there is no god except Allah and I am Allah's messenger, except for three situations: married fornicator, and life for life, and leaver of Islam and divider of the community.

The hadith about punishment towards apostate also been reported in the Sunan Ibn Majah (1952), as below:

That the Messenger of Allah (S.A.W) said: "Whoever changes his religion, execute him."

Based on the above sahih hadiths, the punishment for apostasy is made very that apostates should be executed. Therefore, the Islamic jurist unanimously agree on the penalty. 
INTERNATIONAL JOURNAL OF ACADEMIC RESEARCH IN BUSINESS AND SOCIAL SCIENCES Vol. 10, No. 6, June, 2020, E-ISSN: 2222-6990 @ 2020 HRMARS

\section{The Context and Procedure of the Death Penalty}

Although the scholars agreed on the death sentence to the apostate, they had other views on the context of the apostasy and the procedure before the person could be sentenced to death. This is because the penalty involved the objective of Islam (maqasid Syariah) that is to take care of the religion as well as the value of one's life.

From the context of the offence, the Islamic jurist were of the view that only the apostate who renounces Islam through free will and of sound mind will be sentenced to death. However, it is not a crime to outwardly renounce Islam out of fear for one's safety or under duress, as long as one still believed in one's heart. It is clearly stated in the Qur'an (Q16:106) that, the condition for apostasy is that the apostate must be of sound mind and an adult who can make their own decisions without the influence of others. According to the Hanafi school of law and several opinions in the other schools, the apostate has to be in a state of sober (Al-Zuhayli, 2008). Based on the sahih hadith, men and women who are apostate voluntarily will be treated equally under hudud punishments (Ibn Hajar, n.d.).

The context that needs to be examined is that the apostate acts as found through his actions and words. Those acts will reflect the will of his heart. Therefore in the enforcement of law, Muslim scholars agreed that authorities should only concern themselves with external expressions of apostasy. This was clear from the overall Shariah principle that the law does not seek to know what is in people's hearts. The Prophet himself is reported to have said, "I have not been commanded to search in the hearts of men or to open them up" (Al-Baihaqi, 1999). This principle became enshrined in the scholarly maxim that, "The rulings of the Shariah concern the evident and outward, and God concerns Himself with what is in the heart" (Al-Shafi'i, 2001). Al-Shafi i (2001) states that punishment for apostasy can only operate based on outward expression, instructing us, "Know that [the judge's] ruling is based on external reality ( $a$ l-z̧āhir), and he is not making licit what God has prohibited. But God rules on what is internal (al-bātin), because God most high is master of what is internal".

According to some of the Islamic scholars, apostasy becomes a hudud crime if it results in revolt. In this context, a secretly apostate person is different from an apostate who explicitly insulting Islam. Therefore, the hadd law linguistically, means prevention or prohibition from such wrongdoing. The act of insulting was argued as the same as the act of treason thus deserving of death. In other words, the apostate who will be sentenced to death is not simply the person afflicted with doubts, but a rebel who attacks and denounces his country. According to Ibn Humam (d. $681 \mathrm{AH}$ ) on this justification (Ahmad, 2005):

"The reason to kill an apostate is only with the intent to eliminate the danger of war, and not for the reason of his disbelief. The punishment of disbelief is far greater with

God. Therefore, only such an apostate shall be killed who is actively engaged in war;" Therefore, for this very reason, an apostate could be killed if he/she instigates and causes war by his/her influence. This foundation is related to the philosophy of state in Islam, that is, religion and country is intertwined. In the Islamic State, citizenship is directly based on being a Muslim. So to renounce Islam has political implications. This offence seems to be the ideological Companion to the first hadd offence, which is sedition (bughah). Someone who turns traitor to the Islamic State may also take the side of the rival, non-Muslim states and in order to do so may give up Islam for Christianity or whatever. The traitor thus adds to his treachery to the state spiritual treachery. Hence according to Aly Mansour, the very meaning behind the hudud punishments is the protection of the 
whole society. It attempts to prevent further undertaking of these crimes, as the crimes involved in this category have the most serious effect on the community (Muhammad, 1993):

Meanwhile from the procedure of law, there are steps in handling apostate from an advice to repent, to the death sentence. Three Sunni schools of law required giving them a chance, and the Hanafis considered it recommended (Wizarah Awqaf, 1983). The vast majority of Muslim scholars held that this opportunity to recant (take back what was said) should be given, based on a set of Hadiths in which the Prophet mentioned giving apostates a chance to change their minds. Based on a narration in the Sunan al-Sughra (Al-Baihaqi, n. d.):

A man from among the Ansar accepted Islam, then he apostatized and went back to shirk. Then he regretted that, and sent word to his people (saying): "Ask the Prophet S.A.W, is there any repentance for me?". His people came to the Prophet S.A.W and said: "So and so regrets (what he did), and he has told us to ask you if there is any repentance for him?" Then the Verses: "How shall Allah guide a people who disbelieved after their Belief up to His saying: Verily, Allah is Oft-Forgiving, Most Merciful" was revealed. So he sent word to him, and he accepted Islam.

In this case, the period for the apostate to repent is different from one scholar to another. Most legal scholars gave three days or three chances. Ibn Hanbal (d. 855) and Abu Hanîfah (d. 767) gave opinions that the accused person should be given a month to repent. The famous scholar Ibn Hazm (d. 1064) reports one opinion that the apostate should be asked if they want to recant until forever (yustatābu abadan wa lā yuqtalu), on the basis of a statement by Umar and a ruling by the early jurist al-Nakha'i (d. 811) though al-Nakha'i probably meant that a repeat apostate should be given a chance to repent every time) (Ibn Hazm, n. d.).

\section{The Analysis on the Dalil from Al-Qur'an and Hadith}

Generally, based on the above al-Qur'an and Hadith, all of the Islamic jurists whether they are of Sunni or Shi'ite are unanimous that the punishment for a Muslim apostate is death. This sentence is for Muslim apostates who leave Islam on his/her own will, without coercion, consciously as well as adults, who refuse to repent and openly insult Islam. In this case, the apostate deserves to be sentenced to death by the ruler after proper procedures have been taken.

The robustness of the death sentence towards the apostate in the Islamic law is solid and has strong references. Although it is not explicitly stated in the Qur'an, its conviction is strong, based on the sahih narration of hadith. According to the rules of the Usul Fiqh, the ruling in the Islamic law need not necessarily be enshrined in the Quran alone, it is also accepted if the ruling is provided by hadith. As the function of hadith is to state and allocate the law that was not mentioned in the Quran, with the condition that the latter does not contradict to the former.

The view that the death sentence for apostate in the hadith is contrary to the Qur'an, does not mean that the directive of the hadith is rejected as such. This is because the sentence that was recorded in the hadith is very clear, about the offence and the consequence. Meanwhile, the verse of the Quran still in general and does not say that an apostate is free of charge and innocent. In other words, the absence of a clear provision does not mean that there is no penalty at all. As we accept that the act of apostasy is sinful and will have retribution in this world and the hereafter. In the meantime, the death penalty for apostasy does not go against the spirit of "no compulsion in religion" in the verse 256 of Surah Al-Baqarah. The verse is aimed at non-Muslims, who cannot be forced to accept Islam. Islam is not a religion of coercion, because faith must come from belief and a heart that 
INTERNATIONAL JOURNAL OF ACADEMIC RESEARCH IN BUSINESS AND SOCIAL SCIENCES Vol. 10, No. 6, June, 2020, E-ISSN: 2222-6990 @ 2020 HRMARS

surrenders to Allah SWT. This situation is different for those who have embraced Islam, who must obey and comply with all orders and injunctions, including being forbidden to apostatize. The injunctions is clearly stated in verse 217 of Surah al-Baqarah that says (Al-Maraghi, 2001):

Whoever from you that converts back to your previous religion (apostasy) then he will

die as a disbeliever and all his deed shall be void in the World and Hereafter.

Explicitly, the verse explains that the apostate will loss of all his good deed and eventually ending up in Hellfire. But the verse does not explicitly say about the punishment in this world. However, this verse does not deny the retribution for the apostate and the sinful act. In explaining this situation, the Islamic jurist has quoted sources from hadith in clarifying the punishment for this sinner in the exegesis.

However, according to Brown (2017), the statement by a few hadiths about this punishment is not in line with the Prophet SAW practice. His argument was based on the report by Ibn al-Tallā' (d. 1103)(2006) who has said that there is no reliable evidence that the Prophet ever executed anyone for apostasy. When 'Ubaydallah bin Jahsh, one of the Companions, left Islam and became a Christian, the Prophet did not order him punished. This report appears in the Sirah Ibn Ishaq, the Tarikh of alTabari and the Mustadrak al-Hakim (Brown, 2017). Thus, in order to comprehend the dispute, we need to examine the context and the situation of every case. Generally, the practice does not deny the position of the authentic hadith on the death sentence. According to Mohammad Iqbal Siddiq (1979), based on the sayings and doings of our prophet and the action taken by the Caliph Abu Bakar, we cannot easily reject the view of the capital punishment for the apostate (Siddiq, 1979).

In the cases of where apostasy was not punished by death was because the apostasy cannot be proven as various assumptions can be made, that the offender was originally a non-Muslim, the offender was as hypocrites and so on. In other words, the death sentence was not imposed on the Companions to avoid fitna that "Muhammad kills his Companions," and imposes his doctrine on people, or forces them to embrace his religion (Al-Alwani, 2012). It is understood in the law that the existence of an illegal provision does not guarantee a wrongdoing should be happening. This is because the objective of the law is to prevent a crime. An absence of punishment towards apostates during the era of the Prophet SAW shows the noble and glorious nature of the companions. Furthermore, the cases were not about apostasy but that of hypocrisy as some individuals pretend to be Muslims when in fact, they were not Muslims. They had adopted Islam only for fear of death (Kadri, 2012).

Studies have found that contextual factors are also a determinant of capital punishment. The death punishment is only imposed when the apostate shows opposition and insults Islam. Therefore during the Caliph of Abu Bakar, a battle was fought against the apostates for refusing to pay tithes and contesting the ruling of the caliphate. The wisdom behind this rule is to preserve the purity of religion, that the apostate must be compelled to return to Islam, with repentance. This ruling was to protect the religion from attempts to belittle Islam or to undermine its function as the institution on the basis of which the Muslim nation came into being, the Islamic state and the rule of the Islamic law.

However for apostates who renounce Islam neither by insulting Islam nor by opposing the Calliphate as it happened during the reign of Umar al-Khattab (d.644), they will be left free and safe. The same scenario took place during to the Caliph 'Umar bin 'Abd al-'Azīz (d. 720), apostates were allowed to revert to their previous status as a protected non-Muslim minority in northern Iraq (alSan'ani, 1989). However, later Islamic jurist such as Sufyan al-Thawri (d.777) and Ibrahim al-Nakha'i 
INTERNATIONAL JOURNAL OF ACADEMIC RESEARCH IN BUSINESS AND SOCIAL SCIENCES Vol. 10, No. 6, June, 2020, E-ISSN: 2222-6990 @ 2020 HRMARS

(d.811) did not support such a penalty. They opined that the apostates are to be ordered to repent and until then, the apostates were prescribed an indefinite term of imprisonment. Similarly, reformers such as al-Din al-Afghani (1897), Rida (d. 1897) and Abduh (d. 1905) adopted the same approach towards apostates with the benefit of having to express their freedom of religion without compulsion.

The view is in line with the recent study of Nik Rahim (2018) which disputes the death sentence to the apostates. There are certainly strong reasons to take someone's life, such as the apostate must also do something that divides the Muslim community, by spreading hatred or misinformation in Muslim community and stirring them up. So by that definition, an apostate who merely renounces Islam without dividing the Muslim community, does not fall under the category that calls for his death. Thus an apostate in general by the light of that very hadith will not face mandatory fixed death penalty. The sentence of the hadith has a special context in which the apostate has also committed a hate crime against Islam as well as fighting the Islamic caliph. This side leads to the political issue of overthrowing the Islamic government by deceiving the Muslims and instilling hatred for the government. Thus, they deserve the severe punishment. That is why Imam Sarakhsi has different views over punishment for apostates, by separating between the non-seditious religious apostasy and that of seditious and political nature, or high treason (Saeed \& Hassan, 2007).

Based on the theory, Wael Hallaq has stated that "[in] a culture whose lynchpin is religion, religious principles and religious morality, apostasy is in some way equivalent to high treason in the modern nation-state". Moreover, in the early days of Islam, the formulation of a state system was religious and in the event of a religious collapse, it can lead to the collapse of the country. Therefore, one of the pillars of securing the nation, and the existence of the Islamic state, is by protecting its adherents as well as ensuring that they do not apostatize and undermine the religion.

\section{Current Punishment for Apostasy}

Although the majority's views of the Islamic jurist agree on the death penalty for apostasy, but not many death penalty has been implemented. Based on the report by the United States Commission on International Religious Freedom in the year 2006, only four cases of execution for apostasy in the Muslim world have been implemented, that is, one in Sudan in 1985; two in Iran, in 1989 and 1998; and one in Saudi Arabia in 1992. Among Islamic countries, there are more than 20 countries that have laws which declare apostasy by Muslims is a crime. (Wikipedia, 2020)

The apostasy is categorized as a capital offence in Afghanistan, Brunei, Mauritania, Qatar, Saudi Arabia, Sudan, the United Arab Emirates, and Yemen. While some predominantly Islamic countries have prosecuted individuals for apostasy using blasphemy regulations. Under the regulation, the penalty is lighter and does not cause a death sentence. In Malaysia, there are currently five Malaysian states that have a provision about apostasy. The state of Perak (1992), Terengganu (2002), Malacca (1991), Pahang (20013) and Sabah (1992) has promulgated the law with various offence such as apostasy, an attempt to apostate and abetment to apostate (Mohamed Adil, 2007). The penalty is known under takzir category which the court shall, if satisfied that a person has attempted to change the religious beliefs, ordered the person to be detained at the Islamic Guidance Center for a period of not more than 36 months for educational purposes and that person be required to repent accordingly. The offender will be released if they have repented.

Meanwhile in Perak, the provision about apostate is clearer. Section 13 of the Enactment of Criminal (Syariah) has provided that upon conviction of act or words of apostasy, the apostate shall 
INTERNATIONAL JOURNAL OF ACADEMIC RESEARCH IN BUSINESS AND SOCIAL SCIENCES

Vol. 10, No. 6, June, 2020, E-ISSN: 2222-6990 @ 2020 HRMARS

be liable to a fine not exceeding three thousand ringgit or to imprisonment for a term not exceeding two years or both. In 1993 and 2002, Kelantan and Terengganu have promulgated a special Enactment that makes apostasy a crime punishable with death. The law provided that any person convicted of the offence of apostasy shall be required to repent within no less than three days after his conviction. If he refuses to repent, the Court shall declare a sentence upon him and order that his properties that were acquired before or after he committed the offence to be seized by the Baitulmal. However, the sentence cannot be executed as it is null and void as it went against the jurisdiction of the Federal Constitution.

\section{Conclusions}

Based on the above analysis as well as underline verses from the Qur'an and Hadith, an act of apostasy is a sin and forbidden in Islam. Even though the Qur'an does not explain explicitly about the punishment towards the apostate in this world, the notion was explained in hadith. Since the accuracy of hadith is important, the status of hadith with an authentic source and from robust narration cannot deny its validity. Therefore, there is no reason to ignore the meaning of this hadith. As a summary, the majority of Muslim jurists have opined that the apostate must be put to death on the verbal Sunnah and consensus.

However, the context of apostasy is found to be significant to justify the severe penalty towards the apostate. For ordinary apostate who pronounce Islam silently, no punishment will be enforced to him/her as the faith is about an internal belief. However for those insulting Islam and showing hatred by breaking rules and go against the Islamic government, then that kind of apostate should be sentenced with a severe penalty. As Islam is a religion with rules, it carries commands as well as sentences. If one break the command, then he deserves the sentence that provided for the command. That is the right perspective that people have to abide for.

\section{References}

Ahmad, M. T. (2005). The Truth about the Alleged Punishment for Apostasy in Islam. N. p p.: Islam International Publications.

Al-Alwani, T. J. (2012). Apostasy in Islam a historical and scriptural analysis. USA: The International Institute of Islamic Thought.

Al-Bayhaqi, A. B. (1999). al-Sunan al-Kubra. Beirut: Dar al-Kutub al-'llmiyya.

Al-Bayhaqi, A. B. (n. d.). al-Sunan al-Sughra. Beirut: Dar al-Ma'rifah.

Al-Bukhari, M. I. (1422). Sahih Al-Bukhari. Damsyiq: Dar Tauq an-Najaah.

Al-Maliki, M. A. (1989). Minah al-Jalil Syarh mukhtasar Khalil. Beirut: Dar al-Fikr.

Al-Maraghi, A. M. (2001). Tafsir al-Maraghi. Kuala Lumpur: Dewan Bahasa dan Pustaka.

Al-San'ani, A. R. (1983). al-Musannaf. Beirut: al-Maktab al-Islama.

Al-Shafi 'i, M. I. (2001). Kitab al-Umm. Mansoura: Dar al-Wafa'.

Al-Zuhaili, W. (2008). Mausu'ah Al-Fiqh Al-Islami Al-Mu'asir. Syria: Dimashq Dar-al-Maktabi.

Brown, J. (2017). The Issue of apostasy in Islam. USA: Yaqeen Institute for Islamic Research.

Given, L. M., ed. (2008). The Sage Encyclopedia of Qualitative Research Methods. SAGE Publications, Los Angeles.

Hasan, Z., and Ali, M. N. (1987). Kedudukan Murtad Menurut Perspektif Undang-Undang di Malaysia. Diskusi Syariah dan Undang-undang, Fakulti Syariah dan Undang-Undang, Universiti Sains Islam Malaysia on 17 Januari 2007. 
INTERNATIONAL JOURNAL OF ACADEMIC RESEARCH IN BUSINESS AND SOCIAL SCIENCES

Vol. 10, No. 6, June, 2020, E-ISSN: 2222-6990 @ 2020 HRMARS

Ibn Abbas, M. F. (20017). Tanwir al-Miqbas min Tafsir Ibn 'Abbas. Amman, Jordan: Royal Aal al-Bayt Institute for Islamic Thought.

Ibn Abidin, M. A. D. (1992). Hasyiah Ibn 'Abidin. Beirut: Dar Al-Fikr.

Ibn al-Talla', M. F. Q. (2006). Aqdiyat Rasul Allah. Cairo: Dār Ibn al-Haytham.

Ibn Hajar, A. A. (n.d.). al-Diraya fi takhrij ahadith al-Hidaya. Beirut: Dar al-Ma'rifah.

Ibn Hazm (n. d.). Al-Muhalla. Beirut: Dar al-Afaq al-Jadida.

Ibn Majah, A. A. M. (1952). Sunan Ibn Majah. Beirut: Darul Kutub Al Ilmiyyah

Ibn Qudamah, A. A. M. (1983). Al-Mughni. Beirut: Dar al-Kitab al-Arabi.

Ibnu Manzur, M. M. A. (1414H). Lisan al-Arab. Beirut: Dar Sodir

Jalal al-Din, M. A. (1959). Tafsir Al-Jalalayn. Delhi, India: Kutupkhanah-yi Rashidiyyah.

Kadri, S. (2012). Heaven on Earth: A Journey Through Shari'a Law from the Deserts of Ancient Arabia. USA: Macmillan.

Mohamad, M. (1993). Jenayah dalam Islam: Satu Kajian IImiah mengenai Hukum-hukum Hudud. Nurin Enterprise, Kuala Lumpur.

Mathison, S. (1988). Why triangulate? Educational Researcher

Adil, M. A. (2007). Law of Apostasy and Freedom of Religion in Malaysia. in Asian Journal of Comparative Law, 2(1), 1-36.

Muhammad, H. (1993). Islam and Punishment. Lahore, Pakistan: Vision Islamic Publications.

Muslim, A. H. N. (1330). Sahih Muslim. Damsyiq: Dar al-Khilafah al-Ulyah.

Wajis N. R. (2018) Revisiting Law of Apostasy in Islamic Law. Malaysian Journal of Syariah and Law, 6(2), 25-39.

Saeed, A., Hassan, S. (2004). Freedom of religion, apostasy and Islam. USA: Ashgate Publishing Ltd.

Siddiq, M. I. (1979) The Penal Law of Islam. Lahore, Pakistan: Kazi Publication.

Simpson, J. A., Weiner, E. S. C., \& Oxford University Press. (1989). The Oxford English Dictionary. Oxford: Clarendon Press.

Syarbini, M. A. K. (1994). Mughni Al-Muhtaj ila ma'rifah ma'ani alfaaz al-Minhaj. T.tp: Dar al-Kutub al-Ilmiyyah

Walliman, N. (2011) Research Methods the Basic. New York: Routledge.

Wizarat al-Awqaf. (1983). Al-Mawsu'ah al-Fiqhiyya. Kuwait: Wizarat al-Awqaf. 